\title{
Development of E-UETLPE Web Application (UET Online Lecturer Performance Evaluation System)
}

\section{Dr. Anni Dasho Sharko}

Lecturer, Faculty of Economy and Information Technology, European University of Tirana

Email: anni.dasho@uet.edu.al

\section{PhD. Genci Sharko}

Lecturer, Electrical Engineering Faculty, Polytechnic University of Tirana

Email: gsharko@gmail.com

Bora Demi

Graduated Batchelor Economic Informatics-Business Administration Profile, Faculty of Economy and Information Technology, European University of Tirana

Assoc. Prof. Dr. Indrit Baholli

Lecturer, Faculty of Economy and Information Technology, European University of Tirana Email: indrit.baholli@uet.edu.al

Doi:10.5901/jesr.2015.v5n2p93

\section{Abstract}

The Albanian lecturer's staff of Private and State Universities can vary enormously in their ability to teach effectively in years. European University of Tirana (Private University), has implemented many methods to measure this variation but one commonly used method is seen from UET Management staff as the most effective ones in using students' evaluation of lecturers' performance. For many decades, the outcome of students' evaluation of teaching performance is seen from UET Management as an important tool to measure the effectiveness of teaching quality, at the beginning this procedure was in hard copy evaluation process and since the last 2 years it was developed the lecturer online evaluation system, developed locally with a dedicated bachelor students team from economic of informatics profile. UET lecturers manage their day to day operation in their classrooms, and they need to know whether the implementation of their good effective teaching initiatives and strategies used are well received by their bachelor or master students. UET management and academic staff used the most suitable method to measure teaching effectiveness the students' evaluation of lecturers' performance, which is often carried out at the end of each semester of the actual academic year of the European University of Tirana. At the end of this analyses the final report will reflect on qualities associated with good teaching such as lecturers' knowledge, the most updated syllabuses and texts used for teaching, better class management and course organization. The development of this application is done based on the platform of Apache/MySQI/PHP (AMP). The whole platform is working actually on the UET Intranet environment (first phase) and will be developed the second version of this application (second phase), where the application will be developed from master students of Applied Informatics Profile, Economic and Information Technology Faculty, European University of Tirana, where from all students of UET 3 faculties will be accessed and fulfilled online from their home the evaluation application form.

Keywords: web applications, Apache/MySQI/PHP(AMP), students online evaluation, etc...

\section{Introduction}

Development, implementation and usage of web applications are having a great popularity even due to the ability of updating and maintaining web applications without distributing and installing software on potentially 1500-5000 student's computers of European University of Tirana for the whole set of applications developed for UET students' needs and UET Managerial staff needs. 
Web-based applications are:

- easier to be developed from the development teams

- more useful for your users, userfriendly applications

- easier to install and maintain and keep secure the whole application already developed

- easier to grow as the needs from university come and grow time by time

E-Evaluation (UET lecturing performance evaluation) web application is the first web application designed for European University of Tirana, where the outcome of students' evaluation of teaching performance is seen from UET Management as an important tool to measure the effectiveness of teaching quality of all lecturer and seminars teaching at the 3 faculties of UET[1, 2 and 3].

This process, development of E-Evaluation (UET lecturing performance evaluation) web application is one of the biggest ICT Projects (as per UET ICT strategy 2013-2016) designed to be implemented on three phases of the project consisting of:

- $\quad 1^{\text {st }}$ Phase: Analyses, Design/Development, Test and Fully Live of the application on the Intranet Environment of UET. Bachelor Students involved at this process.

- $\quad 2^{\text {nd }}$ Phase: Analyses, Design/Development, Test and Fully Live of the application on the Internet where all students bachelor and master level will receive an email with the proper link where to proceed with their lecturer evaluation process. Master Students involved at this process.

- $\quad 3^{\text {rd }}$ Phase: adding other evaluation processes to the main application:

- Evaluation of Secretary and Coordinators

- Other evaluation forms UET Administrative/Management staff uses for measuring the performance of their lecturer/seminars staff during the academic years.

We aim to present a mostly complete view of our application focusing especially on the design process and the pre-analyses done before arriving to the needs of this development.

\section{Further Analyses on Developing E-UETLPE (UET Online Lecturing Performance Evaluation) Web Application}

This study aimed to support with the development of the web application platform the Management/Academic Staff to investigate the students' perceptions of lecturers' performance at the end of the semester in order to gauge the overall teaching quality of the lecturers assigned to teach them throughout the whole semester, based on the bachelor/master course syllabuses, the mandatory literature, mandatory PowerPoint presentations used, other video visual materials used to the benefit of the subject [3 and 4].

Evaluation of teaching effectiveness at the European University of Tirana is considered a critical element in determining whether or not UET faculty members are retained at higher education institutions.

This study compares two methods of student evaluations of faculty since the beginning of functional analyses online versus the traditional paper format and the findings suggested that conducting faculty evaluations through online applications may be a suitable alternative to the traditional, paper-based approach.

\subsection{Which are the main features and benefits of the UET online Lecturer evaluation application.}

Evaluating lecturing staff and academic subject's bachelor and master levels can be a challenging task for any private or state universities especially for European University of Tirana. Based on the main perception that each private/state university has a unique approach with different requirements, UET lecturers/academic subjects evaluator's features make evaluations fast and accurate.

Using Built-In Form Builder with Pre-Loaded questions:

- What are the students' perceptions towards the teaching performance of lecturers

- What are the students' perceptions towards the bachelor and master academic courses (syllabuses, PowerPoint presentations, mandatory and recommended literature, audio-visual materials)?

\subsubsection{Real-Time Reports}

Data is always at your fingertips with reports that track and compare how your teachers are performing individually, by department and by faculty within the European University of Tirana, at bachelor and master levels. 


\subsubsection{Evaluation Scheduler for Master and Bachelor level for each UET Faculties}

Evaluation Scheduler to help manage the whole month of evaluation for all three faculties bachelor and master levels, schedule evaluations and receive reminders on upcoming evaluations.

\subsubsection{Improve Communication between Evaluator \& Lecturer}

Once the evaluations are completed, lecturers are automatically notified via e-mail from the system and are provided with a direct link to view their evaluation online on the evaluation web based platform. There is even to be taken under consideration the self-evaluations process to be conducted by lecturers to encourage professional development.

Specifically, the application aims to get the answers of the following research questions used for the evaluation of the lecturer and the academic subjects from the students:

1. What are the students' perceptions towards the teaching performance of lecturers?

a) The lecturer makes clear the lecture/seminar objectives hourly.

Pedagogu i bën të qarta objektivat e leksionit dhe seminarit në çdo orë.

b) The lecturer clearly explains all parts of the lecture and he creates a positive environment in the class.

c) The lecturer is clear when he is passing from one subject to the next one.

d) The lecturer uses different techniques to make the subject more attractive for his students.

e) The lecturer gives to his students the opportunity to raise questions and develop the creative debate between them.

f) The lecturer owns the creative debate among his students.

g) The lecturer promotes critical thinking in his students.

h) The lecturer through project courses aims to generate quality work.

i) The lecturer uses the available teaching schedule effectively and efficiently.

j) The lecturer enables his student's lecturer in written and oral communications (referring to the nature of the object).

k) The lecturer is willing to help his students after lecturer time and during tutorial hours every Friday 3-5 p.m.

2. What are the students' perceptions towards the bachelor and master courses (syllabuses, PowerPoint presentations, mandatory and recommended literature, audio-visual materials etc...)?

a) Mandatory Literature is up-to-date?

b) The material that is presented to the students by the lecturer is well organized?

c) Research papers and articles recommended to be used by students are up-to-date?

d) The recommended literature helps you to understand and get more of the content?

e) Audio visual materials, case studies, etc... used during the lectures are available to the better understanding of the subject?

While the results analyses from paper-based and online evaluation methods done to the European University of Tirana respectively 2010-2012 and $2013-2015$ seem equivalent, and the online evaluation response rate typically falls below that of the paper-based response rate.

From the first perception of the evaluation of both methods we came at the idea that various factors may explain lower online rates:

- online surveys involve out-of-class time,

- students can be distracted and not remembering the dedicated evaluation period,

- or simply choose not to take the time to complete the evaluation process.

- technical problems may also be there during the accessing process of surveys online,

- students concerns persist about whether their responses are anonymous or not,

This year before we go ahead with the best solution of on-line evaluation system, we came again at the major concern that filling out numerous on-line surveys may cause to our students to reach a saturation point and decline some or all evaluations through the on-line system. 


\section{Web Applications, Classifications, Architecture and Technology Used}

A Web Application is a software product designed to be executed in the World Wide Web environment, where several architectures and technologies have been proposed and used to implement and deploy Web Applications.

Web Applications have some characteristics that influence their life cycle and differentiate them from traditional application.

An indicative list of these characteristics could be the following:

- The main purpose of a Web Application usually consist in data storing and browsing

- Web Applications are always interactive applications where usability is a fundamental quality factor for them

- Web Applications are always concurrent applications and the number of contemporary users may vary in unpredictable way

- Web Application developers are usually low-skilled people

- Web Applications need a continue evolution, for technological and marketing reasons

- Web Applications must be developed in a very short time, due to the pressing short time-to- market.

\section{Web Application Analysis and Definition}

The detailed analyses consisted on several meetings and interviews done with the HR and Curricula Department, PR and Communication staff, three Faculty Deans, Rector and Deputy Rectors, Head of Faculty Departments the requirements specification document was created for developing web applications as: E-UET Lecture Evaluation, UET Intranet, E-UET Students Care Application. Review of existing documentations helped us on understanding all elements of actual on-line and traditional hardcopy evaluation process. The whole database platform already existing in old version of on-line evaluation process, was a good reference when working for the final requirements specification document for E-UET Lecture Evaluation, UET Intranet, E-UET Students Care Web applications [6 and 7].

Project Methodology used

- First phase had the following sub-phases:

- Analysis and Definitions

- Implementation (Active development)

- Backup Policy (daily, weekly during the evaluation period per each semester).

- Second phase had the following sub-phases:

- Final preparation (Migration, Integration tests, Documentation, user training)

- Simulation before Going LIVE supporting the total number of UET students.

- Go Live in 2 phases

- First Phase testing with Master Students of Informatics Economics

- Second phase Go-Live with full application.

In general, all UET students accessing the application form Intranet or Internet environment founded the importance of such application and how useful was for all students such a platform. The success or the failure of a software system depends mostly on its utilization.

\section{Software Design, Data and Software Model}

For UET On-Line Evaluation Application we have chosen the WAMP platform as a dynamic web-based application of type client-server developed and implemented in a Windows-Apache-MySQL-PHP platform. The application is installed once in the server and, all students, lecturer, and the top management staff of UET can access and use the application from their computers home/office all over the Internet [3, 7, and 8].

Realizing such a web application for on-line evaluation process for the lecturing and lecturer, we designed web application based on the platform Apache/MySql/PHP with following versions of the components:

Apache 2.2.14, MySql 5.1.44, PHP 5, PhpMyAdmin 3.2.4

- The database of this application will be designed in MySql platforme.

- The on-line evaluation application will be available over the UET Intranet platform the 1st phase and later on will be accessible even through the internet.

- The web application is not depandable from the operating system of the server Windows/Linux optional to be choosen. 
- The application can be accessed from different browsers, but preferable will be Mozilla.

- The users(students, session manager, UET-HR users) have different rights and not overlapping with each other.

- The basic reports is based on the functional requirements elements.

We mentioned that for development of such applications the most important is:

- Presentation layer, that is responsible of the user interface,

- Content layer, that is responsible of the textual part of the application;

- Application layer, that is responsible of the business logic of the application:

- Data and Service layer, that is responsible of the data exchanges between the applications and third parties, such as databases or service providers.

After the analyses phase based on the collaboration of functional and IT it was agreed for the further steps on the software design part as usually considered as the most crucial one or the success of a UET On-Line evaluation Application development part. It consists in developing a database and software model which will interact with the database for storing, modifying and retrieving proper data.

The first step in this phase was modeling the real world system in a well-structured database (used the same table structure as UMS main students application system). This model is represented by the logical database schema as shown in figure 1 and figure 2 .
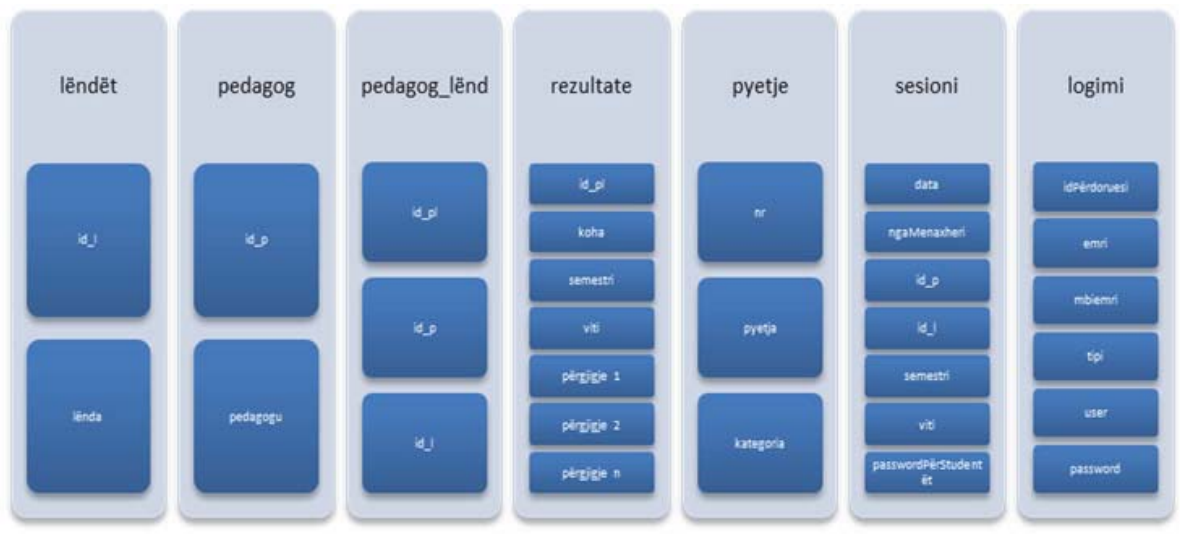

Figure. 1. Main Tables and their fields of UET On-Line Evaluation Database.

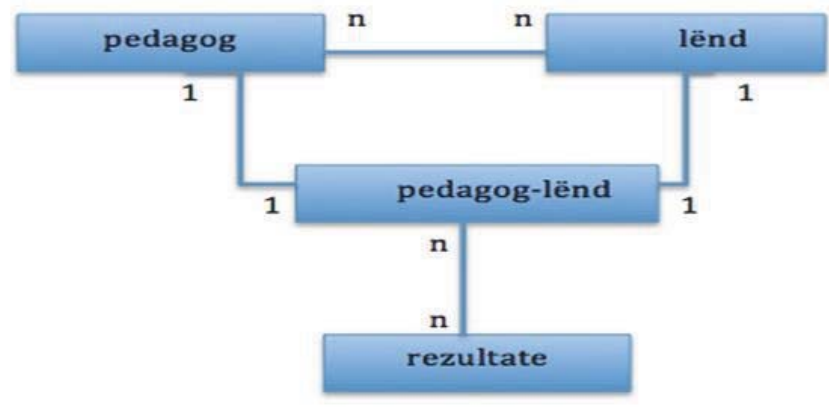

Figure. 2. Logical Database Schema of UET On-Line Evaluation Application

During the designing of the UET On-Line Evaluation Database, we have done the proper analyses of the real world system and model it in a database. A well-designed database takes time and effort to conceive, build and refine, this was done for UET On-Line Evaluation Application. 

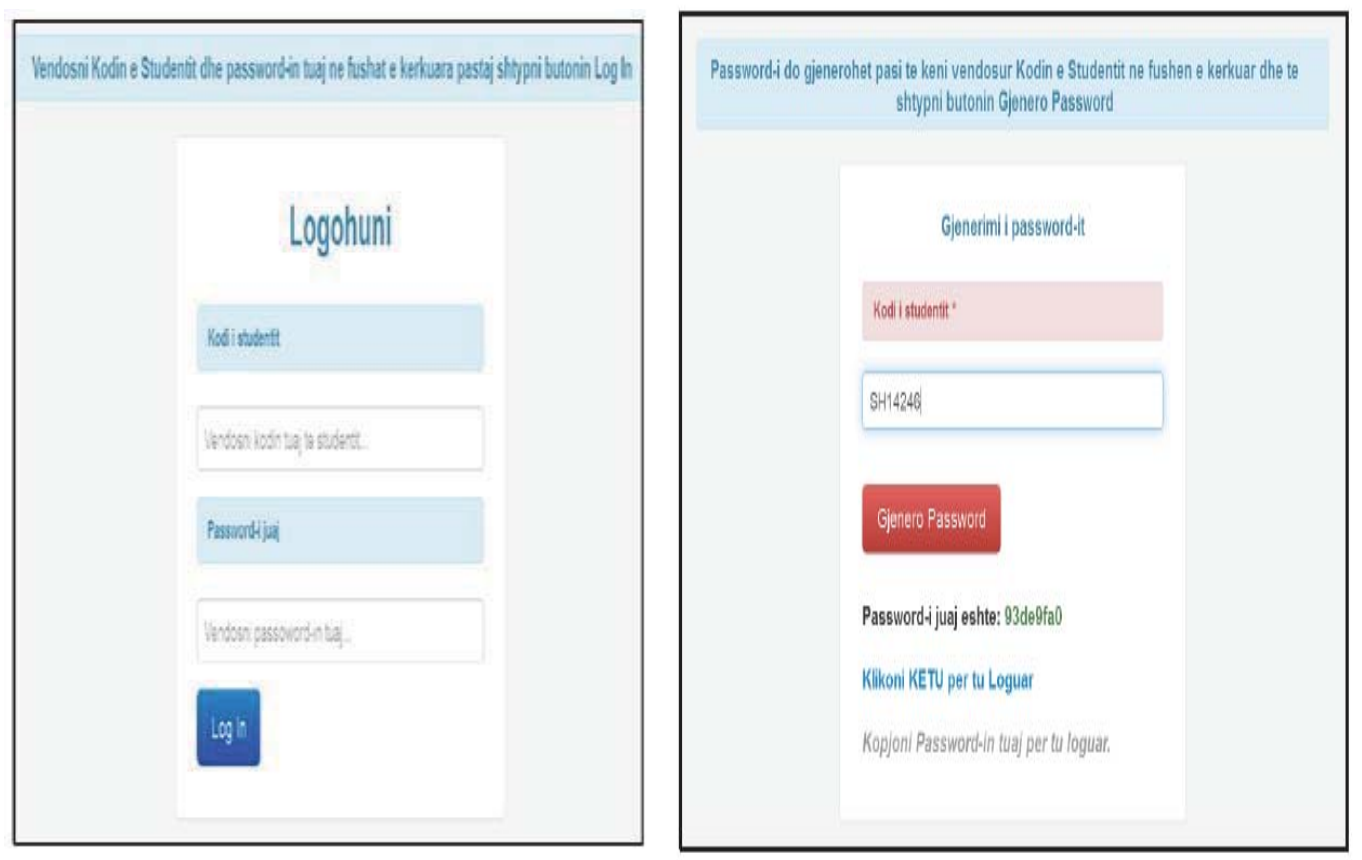

Fig. 3. Login form for the UET Students. Fig. 4. Password generation UET student's code.

Ju po plotesoni formularin per pedagogun Elvin Meka dhe lenden Tregjet financiare te vitit akademik2012/2013, semestri 1

\begin{tabular}{|c|c|c|c|c|c|}
\hline VLERESMII I PEDACOCUT NGA STUDENTI & $\begin{array}{c}\text { Nuk jam } \\
\text { aspak dakord }\end{array}$ & $\begin{array}{l}\text { Nuk jam } \\
\text { dakord }\end{array}$ & Nuk e di & Jam dakord & $\begin{array}{l}\text { Jam plotesisht } \\
\text { dakord }\end{array}$ \\
\hline Pedagogu I běn tě qarta objektivat e leksionit dhe seminarit & 0 & 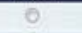 & 8 & - & 0 \\
\hline Pedagogu shpjegon qaartë të gijthë pjesët e leksionit dhe krijon një mjedis pozitiv në klasë. & 0 & 0 & 0 & o & 0 \\
\hline Pedagogu ështe I qartë kur kalon nga një temê në tjetrën. & 0 & 0 & 0 & 0 & 0 \\
\hline Pedagogu përdor teknika të ndryshme për ta bërě lëndën sa më tërhequèse. & ○ & 0 & 0 & 0 & 0 \\
\hline Pedagogu i jep mundësi studentëve tẽ ngrejnë pyetje dhe zhvillojnë debate mes tyre. & 0 & 0 & 0 & 0 & ○ \\
\hline Pedagogu e zotëron debatin mes studentêve & 0 & 0 & 0 & (c) & 0 \\
\hline Pedagogu e promovon mendimin kritik tek studentēt. & 0 & 0 & 0 & 0 & 0 \\
\hline Pedagogu nëpẽrmjet detyrave tẽ kursit, synon tẽ gjenerojë punime cilesore. & 0 & 0 & 0 & 0 & 0 \\
\hline Pedagogu e përdor orarin e mësimit në dispozicion nẽ měnyrẻ efektive dhe eficiente. & 0 & 0 & 0 & 0 & 0 \\
\hline $\begin{array}{l}\text { Pedagogu i aftěson studentēt nĕ komunikime me shkrim dhe gojë (duke iu referuar natyrës së } \\
\text { lëndës). }\end{array}$ & 0 & 0 & 0 & 0 & 0 \\
\hline Pedagogu ështẽ i gatshēm pēr tẽ ndihmuar studentët jashtē klase dhe gjatẽ tutoriatit. & 0 & 0 & e & 0 & 0 \\
\hline
\end{tabular}

\begin{tabular}{|c|c|c|c|c|c|}
\hline VLERESIMI PER KURSIN NGA STUDENII & $\begin{array}{l}\text { Nuk jam } \\
\text { aspak dakord }\end{array}$ & $\begin{array}{l}\text { Nuk jam } \\
\text { dakord }\end{array}$ & Nuke di & Jam dakord & $\begin{array}{l}\text { Jam plotesisht } \\
\text { dakord }\end{array}$ \\
\hline Teksti bazë për lëndën është bashkëkohor. & 0 & 0 & 0 & 0 & 0 \\
\hline Materiali q̣e i paraquitet studenteve nga pedagogu eshte i mire organizuar & 0 & 0 & 0 & ○ & 0 \\
\hline Artikutj shkencorë tê rekomanduara për lëndën, janě bashekohorè & 0 & 0 & 0 & 0 & 0 \\
\hline Literatura e rekomanduar ju ndihmon për tẽ kuptuar më shumë nga lënda. & 0 & o & 0 & 0 & 0 \\
\hline 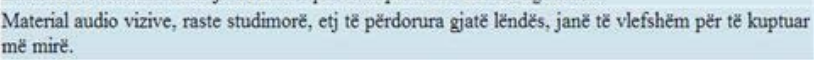 & 0 & 0 & 0 & 0 & 0 \\
\hline
\end{tabular}

Figure 5. Evaluation form to be fill in for the lecturer and the subject 


\begin{tabular}{|c|c|c|c|c|c|}
\hline VLRRSMII I PDAGOGUT NGA STUDEMII & $\begin{array}{c}\text { Nukjim } \\
\text { spak dakord }\end{array}$ & $\begin{array}{l}\text { Nakjum } \\
\text { dakord }\end{array}$ & Nukedi & Jam dakord & $\begin{array}{l}\text { Jam plotesinht } \\
\text { dakord }\end{array}$ \\
\hline Pedagogu I bẻn tê qarta objektivat e leksionit dhe seminarit & $(0 \%)$ & $(0 \%)$ & $(0 \%)$ & $(0 \%)$ & $(0 \%)$ \\
\hline Pedagogu shpjegon gartë tẽ githè pjesête e leksionit dhe krijon nje mje & $(0 \%)$ & $(0 \%)$ & $(0 \%)$ & $(0 \%)$ & $(0 \%)$ \\
\hline Pedagogu ështe I qaartê kur kalon nga njē temẽ nẽ țetrēn. & $(0 \%)$ & $(0 \%)$ & $(0 \%)$ & $(0 \%)$ & $(0 \%)$ \\
\hline 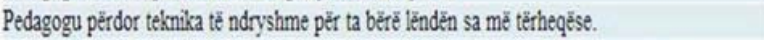 & $(0 \%)$ & $(0 \%)$ & $(0 \%)$ & $(0 \%)$ & $(0 \%)$ \\
\hline Pedagogu i jẹp mundêsi studentêve tẽ ngrejnè pyetje dhe zhvillojnẽ debate mes tyre. & $(0 \%)$ & $(0 \%)$ & $(0 \%)$ & $(0 \%)$ & $(0 \%)$ \\
\hline Pedagogu e zotëron debatin mes studentëve & $(0 \%)$ & $(0 \%)$ & $(0 \%)$ & $(0 \%)$ & $(0 \%)$ \\
\hline Pedagogu e promovon mendimin kritik tek studentêt. & $(0 \%)$ & $(0 \%)$ & $(0 \%)$ & $(0 \%)$ & $(0 \%)$ \\
\hline Pedagogu nểpèrmjet detyrave tẽ kursit, synon tẽ genenerojē punime cilessore. & $(0 \%)$ & $(0 \%)$ & $(0 \%)$ & $(0 \%)$ & $(0 \%)$ \\
\hline Pedagogu e pẹrdor orarin e mësimit në dispozicion nē mënyrē efektive dhe eficiente. & $(0 \%)$ & $(0 \%)$ & $(0 \%)$ & $(0 \%)$ & $(0 \%)$ \\
\hline $\begin{array}{l}\text { Pedagogu i aftëson studentêt në komunikime me shkrim dhe gojez (duke iu refenuar natyrës sễ } \\
\text { lëndēs). }\end{array}$ & $(0 \%)$ & $(0 \%)$ & $(0 \%)$ & $(0 \%)$ & $(0 \%)$ \\
\hline 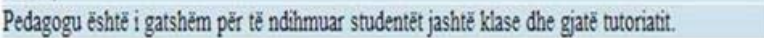 & $(0 \%)$ & $(0 \%)$ & $(0 \%)$ & $(0 \%)$ & $(0 \%)$ \\
\hline
\end{tabular}

Figure 6. Evaluation Report to be generated online after the evaluation process from the students on-line from home or UET Intranet environment.

An effective data model completely and accurately represents the data requirements of the end users. The model used for UET On-Line Evaluation Application eliminates redundant data, it is independent of any hardware and software constraints, and can be adapted to changing requirements with a minimum of effort [ 6 and 7$]$.

In figure 2 is shown the most important entities of the model and their relationships, where this core model was achieved after consulting several times the requirements specification document in order to assure the best modeling of the real world system. The further step was designing the software model and it was already agreed to use ObjectOriented Modeling as one of the most used techniques based on the advantages it offers.

The next step is the implementation of the software for interacting with the database and most importantly offering a user friendly interface to do so.

The communication between the database and the software includes:

- Storing data/information into the database

- Modifying data/information already stored in the database

- Retrieving and consulting data/information

Each user of the application should fill identification requirements in order to login in its personalized interface and use the application and its features.

\section{Conclusions}

With the initiative of the Information Technology, Math and Statistics Department, Economic and Information Technology Faculty, European University of Tirana and full support of Rector, Vice Rectors and Deans of three faculties of European University of Tirana it was established a dedicated team for the analyses, design and implementation of E-UET Lecturer on-line evaluation web application. Encouraging UET students' community acceptance and adoption of Web applications calls for initiatives to make such applications more broadly useful to users in their daily activities. To this end, we claim that a path - based incremental development approach, in which users are involved in evaluating each increment, is a good approach for appropriate technology Web applications.

UET lecturers as they manage their day to day operation in their classrooms, and they need to know whether the implementation of their good effective teaching initiatives and strategies used are well received by their bachelor or master students, based on that UET management and academic staff used the most suitable method to measure teaching effectiveness the students' evaluation of lecturers' performance, which is often carried out at the end of each semester of the actual academic year of the European University of Tirana.

At the end of this analyses the final report will reflect on qualities associated with good teaching such as lecturers' knowledge, the most updated syllabuses and texts used for teaching, better class management and course organization. 
The development of this application is done based on the platform of Apache/MySQI/PHP (AMP). The whole platform is working actually on the UET Intranet environment (first phase) and will be developed the second version of this application (second phase), where the application will be developed from master students of Applied Informatics Profile, Economic and Information Technology Faculty, European University of Tirana, where from all students of UET 3 faculties will be accessed and fulfilled online from their home the evaluation application form.

\section{References}

Anderson, J. \& Brown, G. \& Spaeth, S. (2006). Online student evaluations and response rates reconsidered, Innovate: Journal of Online Education, 2(6).

Anderson, H. M., Cain, J., \& Bird, E. (2005). Online course evaluations: Review of literature and a pilot study. American Journal of Pharmaceutical Education, 69(1), 34-43.

Ravelli, B. (2000). Anonymous online teaching assignments: Preliminary findings. Paper presented at Annual National Conference of the American Asociation for Higher Education, Charlotte, North Carolina.

Thorpe, S. W. (2002 June). Online student evaluation of instruction: An investigation of non-response bias.

Paper presented at the $42^{\text {nd }}$ Annual Forum of the Association for Institutional Research, Toronto, Ontario, Canada.

Lewis, John; Loftus, William (2008). Java Software Solutions Foundations of Programming Design 6th ed. Pearson Education Inc. ISBN 0-321-53205-8.,

Lane, D. and Williams, H. E., (2004). Web Database Applications with PHP and MySQL. O'Reilly.

Greenspan, J., Wall, D. and Bulger, B. (2004). MySQL/PHP Database Applications. Wiley. 